\title{
PENGARUH WCT, DER TERHADAP ROE PADA INDUSTRI MANUFAKTUR DI BURSA EFEK INDONESIA YANG GO PUBLIK.
}

\author{
Roy Hisar, Jaka Suharna \\ Fakultas Ekonomi dan Bisnis, Universitas Esa Unggul \\ Jalan Arjuna Utara No. 9, Kebon Jeruk, Jakarta 11510 \\ Royhisar@esaunggul.ac.id
}

\begin{abstract}
Abstrak
This study aims to determine the effect of Working Capital Turnover (WCT), Debt Equity Ratio (DER) simultaneously on Return On Equity (ROE). The research samples used in this study were 65 companies, namely the Basic Industry and Chemical companies which were listed on the Indonesia Stock Exchange during 2013-2017. The data analysis used was ANOVA and Partial Regression test. The results showed that WCT and DER had a significantly positive effect on ROE from the results of research on the Basic and Chemical Industry companies, so that accounting information has a value of relevance to investment decisions. Working Capital Turnover Variable, partially has a significant negative effect on Return On Equity. Debt Equity Ratio variable partially has a significant negative effect on Return On Equity.
\end{abstract}

Keywords : Working Capital Turnover, Debt Equity Ratio, Return On Equity

\begin{abstract}
Abstrak
Penelitian ini bertujuan untuk Untuk mengetahui pengaruh Working Capital Turnover (WCT), Debt Equity Ratio (DER) secara simultan terhadap Return On Equity (ROE). Sampel penelitian yang digunakan dalam penelitian ini sejumlah 65 perusahaan yaitu perusahaan Industri Dasar dan Kimia yang listing di BEI selama tahun 2013 - 2017. Adapun analisis data yang digunakan adalah Anova dan uji Regresi Parsial. Hasil penelitian menunjukkan bahwa WCT dan DER berpengaruh positif secara signifikan terhadap ROE dari hasil penelitian pada perusahan Industri Dasar dan Kimia, sehingga Informasi akuntansi memiliki nilai relevansi dengan keputusan investasi. Variabel Working Capital Turnonver, secara parsial berpengaruh negatif yang signifikan terhadap Return On Equity. Variabel Debt Equity Ratio secara parsial berpengaruh negatif yang signifikan terhadap Return On Equity.
\end{abstract}

Kata kunci: Working Capital Turnover, Debt Equity Ratio, Return On Equity

Pendahuluan

Dalam ekonomi pasar bebas, manufakturing biasanya selalu berarti produksi secara massal untuk dijual ke pelanggan untuk mendapatkan laba/keuntungan. Beberapa industri seperti semikonduktor dan baja lebih sering menggunakan istilah fabrikasi dibandingkan manufaktur. Sektor manufaktur sangat erat terkait dengan rekayasa atau teknik. (id.wikipedia.org). Perusahaan Manufaktur merupakan perusahaan yang mengolah bahan mentah (bahan baku) menjadi barang jadi. (N. 2012 Azizah, 2012)

Sektor Industri Dasar dan Kimia merupakan salah satu bagian dari Industri Manufaktur yang mempunyai peranan penting dalam pertumbuhan perekonomian di Indonesia. Sektor ini memproduksi bahan baku dasar dan bahan-bahan kimia. Sektor ini bisa dikatakan sektor yang bertumbuh ataupun sektor siklus karena permintaan yang berubahubah setiap tahunnya. Contoh dari sektor ini adalah industri semen, plastik dan kemasan, kertas dan cairan kimia. Tips berinvestasi di sektor ini adalah dengan memperhatikan permintaan pasar akan produknya. Misalnya saja ketika pemerintah menggenjot infrastruktur maka industri semen akan menggeliat karena permintaan akan semen meningkat akibat proyek infrastruktur.

Return On Equity (ROE) merupakan kemampuan perusahaan dalam menghasilkan laba dengan modal sendiri yang dimiliki oleh perusahaan dinyatakan melalui ROE (Pongrangga, Dzulkirom, \& Saifi, 2015). Hasil perhitungan Return On Equity (ROE) sangat dipengaruhi oleh perolehan laba perusahaan, sehingga semakin tinggi hasil yang diperoleh 
dari perhitungan rasio ini, maka akan menunjukkan semakin baik kedudukan perusahaan. Menurut Irham Fahmi (2011:137), rasio Return On Equity (ROE) disebut juga laba atas equity.

Perputaran Modal Kerja (Working Capital Turnover) menurut Sawir (2009:16) merupakan rasio yang mengukur aktivitas bisnis terhadap kelebihan aktiva lancar atas kewajiban lancar serta menunjukkan banyaknya penjualan yang dapat diperoleh perusahaan untuk tiap rupiah modal kerja. (Widiatmoko timmi - Academia," n.d.)

Debt Equity Ratio (DER) memberikan gambaran terhadap nilai hutang yang dimiliki oleh suatu perusahaan. Semakin besar nilai Debt Equity Ratio (DER) maka semakin besar risiko operasional perusahaan dan begitupula sebaliknya. Jika rasionya meningkat, ini artinya perusahaan dibiayai oleh kreditor (pemberi hutang) dan bukan dari sumber keuangannya sendiri yang mungkin merupakan trend yang cukup berbahaya.

Salah satu analisis fundamental saham yang paling sering menjadi sorotan para investor adalah Debt Equity Ratio (DER), karena rasio ini memberikan informasi dan gambaran perbanding tentang penggunaan hutang perusahaan dengan ekuitas perusahaan. Kinerja Debt Equity Ratio (DER) merupakan salah satu indikator yang memberikan kontribusi positif terhadap kinerja Return On Equity (ROE) perusahaan.

\section{Tinjauan Pustaka \\ Teori Nilai Perusahaan (Value of The Firm Theory)}

Menurut Sujoko dan Soebiantoro (2007)

dalam Sri Hermuningsih (2009) Nilai perusahaan merupakan persepsi investor terhadap tingkat keberhasilan perusahaan yang sering dikaitkan dengan harga saham. Harga saham yang tinggi membuat nilai perusahaan tinggi dan meningkatkan kepercayaan pasar tidak hanya terhadap kinerja perusahaan saat ini tapi juga pada prospek perusahaan di masa mendatang. Memaksimalkan nilai perusahaan sangat penting bagi perusahaan, karena memaksimalkan nilai perusahaan berarti memaksimalkan tujuan utama perusahaan.

\section{Teori Kebermanfaatan Informasi (Useful Information Theory)}

Menurut PSAK nomor 1 bahwa akuntansi di refleksikan di dalam laporan keuangan dan laporan keuangan mempunyai tujuannya adalah memberikan informasi mengenai posisi keuangan, kinerja keuangan, dan arus kas entitas yang bermanfaat bagi sebagian besar kalangan pengguna laporan dalam pembuatan ke putusan ekonomi.

Pengunaan laporan keuangan meliputi investor sekarang dan investor potensial, karyawan, pemberi pinjaman, pemasok dan kreditor usaha lainnya, pemerintah serta lembaga-lembaganya, dan masyarakat. Mereka menggunakan laporan keuangan untuk memenuhi beberapa kebutuhan informasi berbeda.

\section{Laporan Keuangan}

Pengertian Laporan keuangan menurut Ikatan Akuntan Indonesia (2009:1) yaitu: "Laporan keuangan meliputi bagian dari proses laporan keuangan. Laporan keuangan yang lengkap biasanya meliputi neraca, laporan laba rugi, laporan perubahan ekuitas, laporan perubahan posisi keuangan (yang dapat disajikan dalam berbagai cara misalnya, sebagai laporan arus kas/laporan arus dana), catatan dan laporan lain serta materi penjelasan yang merupakan bagian integral dari laporan keuangan."

\section{Analisa Rasio Keuangan}

Salah satu cara yang dapat digunakan untuk menganalisis laporan keuangan yaitu dengan cara menganalisis dan menghitung rasio-rasio keuangan perusahaan. Rasio-rasio tersebut akan digunakan untuk mengetahui dan menilai tingkat resiko yang akan dihadapi, tingkat keuntungan yang diperoleh maupun tingkat kesehatan perusahaan. Analisis rasio keuangan merupakan alat analisis yang dapat menjelaskan hubungan maupun indikator keuangan perusahaan untuk menujukkan perubahan kondisi keuangan dan prestasi kegiatan operasional perusahaan (Fahmi, 2011:108). Analisis rasio keuangan juga dapat diartikan sebagai cara maupun alat yang digunakan untuk membandingkan pos- pos yang terdapat dalam laporan keuangan, yang dapat memberikan gambaran perubahan 
kondisi laporan keuangan.

\section{Rasio Solvabilitas}

Solvabilitas merupakan kemampuan perusahaan untuk melunasi seluruh utang dengan memakai semua aset atau asset menjadi penjamin utang yang menjadi konsep dasar akuntansi. Solvabilitas perusahaan penting untuk diketahui supaya tahu kemampuan perusahaan dalam melunasi atau membayar semua pinjaman melalui jumlah aktiva yang dimiliki yang memengaruhi jenis jenis laporan keuangan. Perhitungan solvabilitas pada setiap perusahaan lebih mudah dilakukan jika sistem akuntansi memakai rasio yang tepat.

\section{Working Capital Turnover (WCT)}

Munawir (2007) mengemukakan bahwa dinyatakan ada tiga konsep definisi modal kerja yaitu : konsep kuantitatif, konsep kualitatif, dan konsep fungsional. Dalam konsep kuantitatif, pengertian modal kerja adalah meliputi seluruh aktiva lancar yang memiliki tingkat perputaran yan pendek yakni berupa kas, piutang, persediaan maupun persekot biaya. Pada konsep kualitatif, modal kerja adalah aktiva lancar yang benar-benar digunakan untuk kegiatan operasional yang telah dikurangi dengan hutang lancar. Sedangkan, konsep fungsional, modal kerja adalah modal yang benar-benar digunakan untuk menghasilkan pendapatan periode berjalan (current income) atau periode saat ini saja bukan untuk periode selanjutnya.

\section{Debt Equity Ratio (DER)}

Debt Equity Ratio (DER) merupakan rasio hutang terhadap modal.Rasio ini mengukur seberapa jauh perusahaan dibiayai oleh hutang, dimana semakin tinggi rasio ini menggambarkan gejala yang kurang baik bagi perusahaan. Peningkatan hutang pada gilirannya akanmemengaruhi besar kecilnya laba bersih yang tersedia bagi para pemegang saham termasuk dividen yang diterima karena kewajibannya untuk membayar hutang lebih diutamakan daripada pembagian dividen (Sartono, 2001).

\section{Return On Equity (ROE)}

Menurut Harahap (2007:156) Return On Equity (ROE) digunakan untuk mengukur besarnya pengembalian terhadap investasi para pemegang saham. Angka tersebut menunjukkan seberapa baik manajemen memanfaatkan investasi para pemegang saham. ROE diukur dalam satuan persen. Tingkat Return On Equity (ROE) memiliki hubungan yang positif dengan harga saham, sehingga semakin besar Return On Equity (ROE) semakin besar pula harga pasar, karena besarnya Return On Equity (ROE) memberikan indikasi bahwa pengembalian yang akan diterima investor akan tinggi sehingga investor akan tertarik untuk membeli saham tersebut, dan hal itu menyebabkan harga pasar saham cendrung naik.

\section{Pengembangan Hipotesis Hubungan Working Capital Turnover dengan Return On Equity}

Rasio perputaran modal kerja adalah perbandingan antara penjualan dengan modal kerja bersih suatu perusahaan. Nilai modal kerja bersih diperoleh dari aktiva lancar dikurangi utang lancar. Perputaran modal kerja akan berpengaruh terhadap kebutuhan modal kerja dengan jumlah pengeluaran setiap hari yang tetap dan makin lama perputarannya maka jumlah modal kerja yang diperlukan menjadi semakin besar sehingga perputaran modal kerja dapat dinilai untuk menilai keefektifan modal kerja yang digunakan karena perputaran modal kerja menunjukan penjualan yang dihasilkan dari modal kerja yang digunakan.

\section{Hubungan Debt Equity Ratio dengan Return On Equity.}

Rasio ini memaparkan porsi yang relatif antara ekuitas dan utang yang dipakai untuk membiayai aset perusahaan. Debt to Equity Ratio (DER) membandingkan antara total kewajiban (liabilities) dengan ekuitas (equity). Utang tidak boleh lebih besar dari modal supaya beban perusahaan tidak bertambah. Tingkat rasio yang rendah berarti kondisi perusahaan semakin baik karena porsi utang terhadap modal semakin kecil.

Berdasarkan hipotesis penelitian yang telah diuraikan di atas, maka model penelitian ini : 


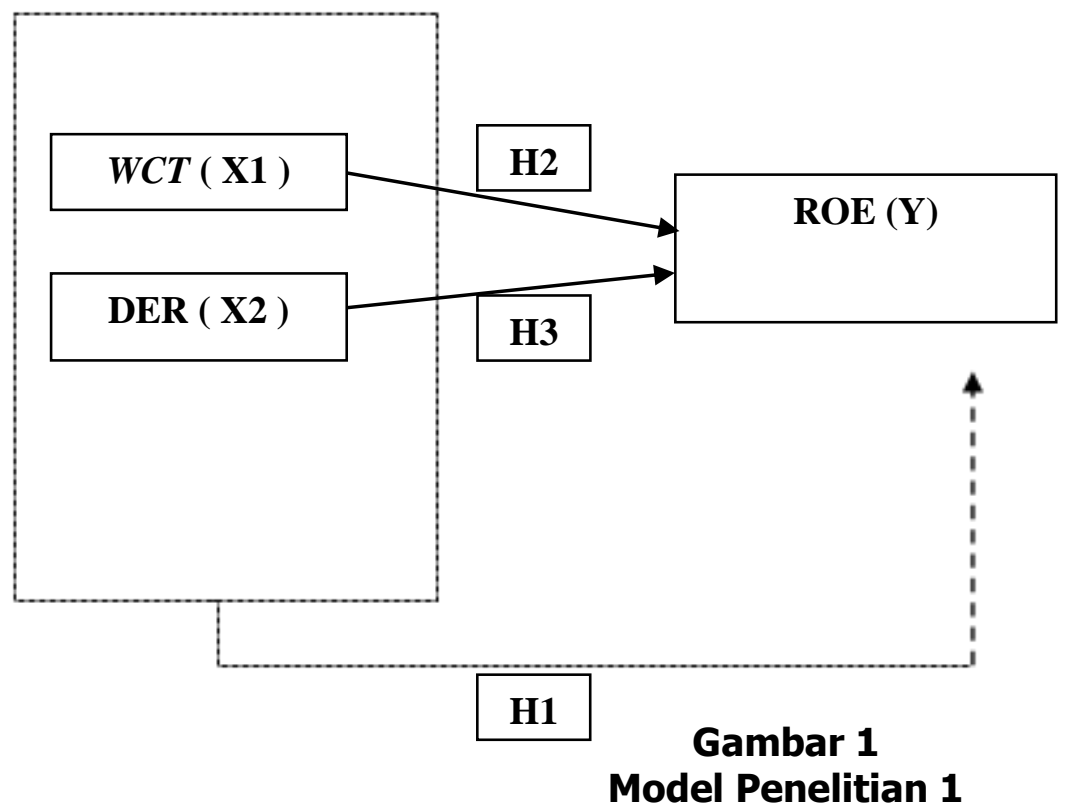

Hipotesis penelitian yang dapat penulis sampaikan yaitu :

H1 : Diduga WCT dan DER terdapat pengaruh Simultan terhadap ROE.

H2 : Diduga terdapat Pengaruh Positif WCT Perusahaan terhadap Return On Equity.

H3 : Diduga terdapat Pengaruh Negatif DER Perusahaan terhadap Return On Equity.

\section{Metode Penelitian}

Metode penelitian yang digunakan adalah metode penelitian kausalitas. Penelitian kausalitas merupakan kegiatan penelitian yang berusaha mencari informasi tentang mengapa terjadi hubungan sebab akibat. Jenis data yang digunakan dalam penelitian ini adalah data sekunder yaitu data kuantitatif yang diperoleh dari BEI atau www.idx.co.id Sedangkan data yang digunakan penelitian ini adalah laporan tahunan perusahaan untuk periode 2013-2017 pada perusahaan sektor Industri Dasar Dan Kimia yang terdaftar di BEI.

Data yang digunakan pada penelitian ini adalah data kuantitatif yaitu data yang berupa kumpulan angka-angka atau data perusahaan yang berhubungan dengan tata kerja organisasi. Sumber data yang gunakan dalam penelitian ini adalah data sekunder yaitu berasal dari dokumentasi perusahaan. Berupa laporan keuangan dan laporan tahunan perusahaan subsektor Industri Dasar dan Kimia dari tahun 2013 sampai dengan tahun 2017.

Pemilihan sampel dilakukan dengan menggunakan metode purposive sampling dengan tujuan populasi yang dijadikan sampel penelitian adalah populasi yang memenuhi kriteria sampel tertentu sesuai tujuan penelitian. Uji normalitas bertujuan untuk menguji apakah model regresi, variabel pengganggu atau residual memiliki distribusi normal (Ghozali, 2012). Dalam uji normalitas ini ada dua cara untuk mendeteksi apakah residual berdistribusi normal atau tidak, yaitu dengan analisis grafik dan uji statistik (Ghozali, 2012). Alat uji yang digunakan adalah dengan analisis grafik histogram dan grafik normal probability plot atau uji statistic dengan KolmogorovSmirnov Z(I-sample diterima nilai Sig $>0,05$. Uji Regresi Simultan (Uji F)/ANOVA, pengujian ini untuk menunjukan apakah semua variabel independen yang dimasukkan dalam model mempunyai pengaruh secara bersama-sama terhadap variabel dependen. Dengan tingkat signifikasi sebesar $5 \%$ maka kriteria pengujian adalah sebagai berikut, bila nilai signifikansi $f$ $<0,05$, maka HO diterima, artinya terdapat pengaruh yang signifikan antara semua variabel independen terhadap variabel dependen. Apabila nilai signifikansi $f>0,05$, maka $\mathrm{HO}$ ditolak, artinya kedua variabel independen tidak berpengaruh terhadap variabel dependen. Uji Regresi Parsial (Uji $t$ ), pengujian ini menunjukkan seberapa jauh pengaruh satu variabel independen secara inudvidual dalam menerangkan variasi variabel dependen. Bila nilai signifikansi $\mathrm{t}<0,05$, maka HO ditolak, artinya terdapat pengaruh yang signifikan 
antara satu variabel independen terhadap variabel dependen. Apabila nilai signifikansi $t>$ 0,05, maka HO diterima, artinya tidak ada pengaruh yang signifikan antara satu variabel independen terhadap variabel dependen.

Uji Koefisien Determinasi $\left(R^{2}\right)$ digunakan untuk menggambarkan kemampuan model menjelaskan variasi yang terjadi dalam variabel dependen. Dengan pengukuran koefisien determinasi ini akan dapat diketahui seberapa besar variabel independen mampu menjelaskan variabel dependennya, sedangkan sisanya dijelaskan oleh faktor lain diluar model. Koefisien determinasi (R2) dinyatakan dalam persentase. Nilai koefisien korelasi (R2) ini berkisar antara $0<R 2<1$. Semakin besar nilai yang dimiliki, menunjukan bahwa semakin banyak informasi yang mampu diberikan oleh variabel-variabel independen untuk memprediksi variansi variabel independen. Dalam penelitian ini terdapat 2 jenis variabel, yaitu: variabel independen (bebas) dan variabel dependen (terikat). Berikut ini adalah penjelasan masing- masing variabel, yaitu: Variabel Independen (X), variabel independen adalah variabel yang mempengaruhi perubahan dalam variabel dependen dan mempunyai hubungan yang positif atau negatif terhadap variabel dependennya. Variabel Dependen $(Y)$ adalah variabel yang dipengaruhi oleh variabel independen. Variabel dependen dalam penelitian ini adalah Return On Equity (ROE) pada perusahaan Sektor Industri Dasar dan Kimia yang terdaftar di Bursa Efek Indonesia.

\section{Hasil dan Pembahasan Statistik Deskriptif}

Deskriptif statistik ditunjukan oleh nilai minimum, maksimum, rata-rata dan standart deviasi. Hasil statistik deskriptif di atas menunjukkan dari 39 data variabel Return On Equity (Y) mempunyai nilai mean sebesar 11.7433 dengan nilai maksimum sebesar 22.27 dan nilai minimum sebesar 1.78 serta nilai standar deviasi sebesar 5.82900. Mean senilai 11.7433 memiliki arti bahwa Return On Equity rata-rata Perusahaan Industri Dasar dan Kimia naik sebesar $1.174 \%$. Nilai maksimum sebesar 22.27 merupakan nilai yang sangat tinggi dalam perolehan Return On Equity yaitu sebesar $2.227 \%$, sedangkan nilai minimum sebesar 1.78 memiliki arti bahwa ROE perusahaan mengalami penurunan yaitu sebesar $178 \%$. Dari 39 data variabel Working Capital Turnover (X1) mempunyai nilai mean sebesar 3.5187 dengan nilai maksimum sebesar 17.08 dan nilai minimum sebesar 0.56 serta nilai standar deviasi sebesar 3.76877. Mean senilai 3.5187 memiliki arti bahwa Working Capital Turnover rata-rata Perusahaan Industri Dasar dan Kimia naik sebesar $351.87 \%$. Nilai maksimum sebesar 17.08 merupakan nilai yang sangat tinggi dalam perolehan Working Capital Turnover yaitu sebesar $1.708 \%$, sedangkan nilai minimum sebesar 0.56 memiliki arti bahwa WCT 56\%. Dari 39 data variabel DER (X2) mempunyai nilai mean sebesar 0.6692 dengan nilai maksimum sebesar 3.40 dan nilai minimum sebesar 0.07 serta nilai standar deviasi sebesar 0.83472 . Mean senilai 0.6692 memiliki arti bahwa DER rata-rata Perusahaan Industri Dasar dan Kimia naik sebesar $66.92 \%$. Nilai maksimum sebesar 3.40 merupakan nilai yang sangat tinggi dalam perolehan DER yaitu sebesar $340 \%$, sedangkan nilai minimum sebesar 0.07 memiliki arti bahwa DER turun $7 \%$.

\section{Uji Normalitas}

Data yang dapat dijadikan penelitian adalah data yang normal ataupun mendekati normal. Dari hasil data penelitian normal, yaitu data mempunyai (Asymp. Sig) > 0.05 maka distribusi data normal dengan nilai Sig $>0.999$.

\section{Uji Hipotesis}

Uji F (Uji Simultan) Untuk mengetahui apakah variabel-variabel independen secara simultan berpengaruh signifikan terhadap variabel dependen. WCT dan DER berpengaruh positif terhadap ROE perusahaan di Industi Dasar dan Kimia yang tercatat Di BEI. Dari hasil uji F, nilai sig sebesar 0.014 atau lebih kecil dari 0.05 , maka variabel WCT dan DER berpengaruh positif secara simultan yang signifikan terhadap ROE pada perusahaan Industri Dasar dan Kimia yang terdaftar di BEI, pada tahun 2013-2017 atau Ha1 diterima.

Uji T (Uji Parsial) Untuk mengetahui apakah variabel-variabel independen secara parsial berpengaruh atau tidak terhadap variabel dependen. Terdapat pengaruh Negatif WCT, secara parsial terhadap ROE. Dari hasil uji diperoleh nilai sig sebesar 0,540 atau lebih 
besar dari 0,05 dengan demikian variabel WCT secara parsial berpengaruh negatif terhadap ROE diperusahaan Industri Dasar dan Kimia yang tercatat di Bursa Efek Indonesia pada periode 2013-2017 atau Ha3 ditolak. Terdapat pengaruh negatif DER, secara parsial terhadap ROE. Dari hasil uji diperoleh nilai sig sebesar 0,776 atau lebih besar 0,05 dengan demikian variabel DER secara parsial berpengaruh negatif terhadap ROE diperusahaan Industri Dasar dan Kimia yang tercatat di Bursa Efek Indonesia pada periode 2013-2017, sehingga Ha4 ditolak.

Uji Koefisien Determinasi $\left(R^{2}\right)$ digunakan untuk menggambarkan kemampuan model menjelaskan variasi yang terjadi dalam variabel dependen. Koefisien determinasi $\left(R^{2}\right)$ dinyatakan dalam persentase. Nilai koefisien korelasi $\left(R^{2}\right)$ ini berkisar antara $0<R^{2}<1$. Dari hasil Uji Koefisien Determinasi $\left(R^{2}\right)$ diatas menunjukkan bahwa $\mathrm{R}^{2}$ sebesar 0.195.

\section{Analisis Penjelasan}

Terdapat pengaruh positif antara WCT dan DER secara simultan terhadap ROE di Perusahaan Industri Dasar dan Kimia Tahun 2013-2017. Rasio dari WCT, semakin tinggi nilai rasio WCT maka nilai perolehan dari ROE juga akan mengalami peningkatan. Namun berbeda dengan nilai rasio dari $D E R$, apabila nilai rasio DER mengalami penurunan maka nilai Rasio ROE akan mengalami peningkatan di Perusahaan Industri Dasar dan Kimia Tahun 2013-2017. Mereka menjadikan laporan keuangan suatu perusahaan sebagai dasar untuk menahan atau menjual investasi tersebut. Informasi Keuangan Juga diperlukan oleh Pemberi Pinjaman guna untuk memutuskan apakah pinjaman serta bunga atas pinjaman dapat dibayar tepat waktu saat jatuh tempo.

Tidak Terdapat pengaruh WCT secara parsial terhadap ROE. Ini disebabkan nilai perolehan mengalami penurunan, ini berarti jika nilai perolehan rasio WCT rendah maka nilai perolehan rasio ROE akan mengalami penurunan di Perusahaan Industri Dasar dan Kimia Tahun 2013- 2017. Nilai perputaran modal kerja sangat penting untuk melihat berapa modal kerja yang digunakan perusahaan untuk menciptakan tingkat Penjualan yang maksimal yang harapkan bisa menghasilkan laba. Dengan memperhatikan modal kerja akan memungkinkan perusahaan dapat menggunakan sumber dayanya dengan ekonomis sehingga bahaya akan krisis keuangan akan dapat diminimalisir. Namun dalam penelitan ini dari hasil yang diteliti oleh Peneliti, tidak terdapat pengaruh WCT terhadap ROE disebabkan oleh adanya Perusahaan Dasar dan Kimia yang mengalami kerugian. Ini menujukkan bahwa perusahaan yang dimaksud, tidak secara optimal dalam menggunakan sumber dayanya secara ekonomis dalam meningkatkan penjualan.

Tidak Terdapat pengaruh DER secara parsial terhadap ROE. Ini disebabkan adanya kenaikan nilai DER di Perusahaan Industri Dasar dan Kimia Tahun 2013-2017 yang artinya jika nilai DER mengalami kenaikkan, maka nilai perolehan dari ROE yang mengalami penurunan di Perusahaan Industri Dasar dan Kimia Tahun 2013-2017. Debt to Equity Ratio adalah rasio yang menggunakan hutang dan modal untuk mengukur besarnya rasio. DER merupakan rasio yang dipergunakan untuk mengukur tingkat penggunaan utang terhadap total shareholder's equity yang dimiliki perusahaan. DER menunjukan persentase penyediaan dana oleh pemegang saham terhadap pemberi pinjaman. Semakin tinggi rasio, semakin rendah pendanaan perusahaan yang disediakan oleh pemegang saham. Hasil Penelitian dari hasil analisis diperoleh hasil regresi sebagai berikut : Working Capital Turnover dan Debt Equity Ratio berpengaruh secara signifikan terhadap Return On Equity.

\section{Temuan Penelitian}

Terdapat beberapa temuan didalam penelitian ini sebagai berikut WCT dan DER berpengaruh positif secara signifikan terhadap ROE dari hasil penelitian pada perusahan Industri Dasar dan Kimia tahun 2013-2017, sehingga Informasi akuntansi memiliki nilai relevansi dengan keputusan investasi.

\section{Kesimpulan}

Berdasarkan hasil pengujian yang dilakukan, didapatkan kesimpulan sebagai berikut , Variabel Working Capital Turnover, dan Debt Equity Ratio berpengaruh positif secara simultan yang signifikan terhadap Return On Equity. Variabel Working Capital Turnonver, secara parsial berpengaruh negatif 
yang signifikan terhadap Return On Equity. Hal ini dikarenakan perusahaan tidak dapat memaksimalkan Modal Kerja untuk menghasilkan penjualan yang lebih tinggi. Variabel Debt Equity Ratio secara parsial berpengaruh negatif yang signifikan terhadap Return On Equity. Hal ini karena tingkat perbandingan total hutang perusahaan lebih rendah terhadap ekuitas. Ini mencerminkan bahwa, perusahaan Industri Dasar dan Kimia yang tercatat di Bursa Efek Indonesia tahun 2013-2017 rata-rata kurang mampu mengoptimalkan Pendanaan para pemegang saham dalam menghasilkan laba bersih. Analisa penelitian ini terbatas pada perusahaanperusahaan sektor Industri Dasar dan Kimia yang terdaftar di BEI pada tahun 2013-2017. Hal ini mengakibatkan hasil dari penelitian tidak dapat di generalisasi terhadap perusahaan diluar sektor Industri Dasar dan Kimia. Menggunakan sampel pengamatan sebesar 39 sampel yaitu 13 perusahaan sektor Industri Dasar dan Kimia dalam kurun waktu 5 tahun yaitu 2013- 2017, sehingga perlu diadakan pengembangan penelitian yang lebih luas lagi baik secara jumlah perusahaan maupun jumlah tahun. Masih belum mengungkapkan secara menyeluruh faktor-faktor fundamental lainnya yang mempengaruhi Return On Equity perusahaan sehingga perlu penelitian lebih lanjut.

\section{Daftar Pustaka}

Agus Sartono, 2001. Manajemen Keuangan Teori dan Aplikasi. Yogyakarta: BPEFYOGYAKARTA.

Akuntansi itu mudah, "Jenis Laporan Keuangan Menurut PSAK - Akuntansi Itu Mudah," 2019. [Online]. Available: http://www.akuntansiitumudah.com/je nis-laporan-keuangan-menurut- psak/.

Azizah, H. L. M., \& Farah, D. (2018). Pengaruh Rasio Aktivitas dan Rasio Leverage Terhadap Profitabilitas (Studi pada Perusahaan Sub Sektor Food and Beverages yang terdaftar di BEI Periode 2012-2016).

Azizah, N. 2012. (2012). Modul 8 Bioinformatika. Perusahaan Manufaktur, 12-13.
Fahmi, Irham. 2011. Analisis Laporan Akuntansi. Bandung: ALFABETA

Ghozali, Imam. 2012. Aplikasi Analisis Multivariate dengan Program IBM SPSS. Yogyakarta: Universitas Diponegoro

Hajar, L. M (2018) Pengaruh Rasio Aktivitas dan Rasio Leverage Terhadap Profitabilitas.

Handayani, C. (2007). Analisis Pengaruh Proporsi Kepemilikan Saham terhadap Kebijakan Pendanaan dalam Meningkatkan Kinerja Perusahaan (Studi Pada Industri Manufaktur di Bursa Efek Jakarta Periode Tahun 20012005).

Harahap, Sofyan S. 2007. Analisa Kritis Atas Laporan Keuangan. Jakarta : Rajawali Pers

Hariyanti, A. (2016) Pengaruh Modal Kerja Terhadap Profitabilitas Pada PT. Semen Tonasa (Persero) di Kabupaten Pangkep.

IDX, "PT Bursa Efek Indonesia," Idx, 2018. [Online]. Available: https://www.idx.co.id/

Ikatan Akuntansi Indonesia, 2009, Standar Akuntansi Keuangan, PSAK No. 1 : Penyajian Laporan keuangan. Jakarta : Salemba Empat.

Munawir. 2007. Analisis Laporan Keuangan. Yogyakarta : Edisi Empat, Liberty.

Nugroho, E. (2011). Penjualan , Perputaran Modal Kerja , Ukuran Perusahaan Dan Leverage Terhadap Profitabilitas Perusahaan.

R. A., Dzulkirom, M., \& Saifi, M. (2015). Pengaruh Current Ratio, Total Asset Turnover dan Debt To Equity Ratio Terhadap Return On Equity (Studi Pada Perusahaan Sub Sektor Property Dan Real Estate yang Terdaftar Di BEI 
Periode 2011-2014).

S Hermuningsih, DK Wardani (2009). Faktorfaktor Yang mempengaruhi Nilai Perusahaan Pada Perusahaan Yang Terdaftar di Bursa Efek Malaysia dan Bursa Efek Indonesia. Jurnal Siasat Bisnis 13

S. S. Tips, "Pengertian dan Tujuan Laporan Keuangan," 2017. [Online]. Available: https://tipsserbaserbi.blogspot.com/20 17/01/pengertian-dan- tujuan-laporankeuangan.html.

Sujoko dan U.Soebiantoro.2007.Pengaruh Struktur Kepemilikan Saham,Leverage, Faktor Intern dan Faktor Ekstern terhadap Nilai Perusahaan. Jurnal Manajemen dan Kewirausahaan. Vol. 9. No. 1. Maret: 41-48.

U. I., Syarif, S., \& Riau, K. (2012). Pengaruh modal kerja dan perputaran modal kerja terhadap return on equity ( roe ). 